\title{
Hubungan Status Gizi dengan Status Sosial Ekonomi Keluarga Murid Sekolah Dasar di Daerah Pusat dan Pinggiran Kota Padang
}

\author{
Lisbet Rimelfhi Sebataraja, Fadil Oenzil, Asterina
}

\begin{abstract}
Abstrak
Status gizi anak secara tidak langsung berkaitan dengan faktor sosial ekonomi keluarga. Jika status sosial ekonomi rendah maka kebutuhan makanan keluarga akan kurang terpenuhi sehingga anak akan memiliki status gizi kurang. Tujuan penelitian ini adalah untuk mengetahui hubungan status gizi dan status sosial ekonomi keluarga murid SD di pusat dan pinggiran kota Padang. Suatu penelitian analitik secara cross sectional telah dilakukan terhadap 220 orang murid di SDN 08 Alang Lawas sebagai perwakilan SD di pusat kota Padang dan SDN 36 Koto Panjang sebagai perwakilan SD di pinggiran kota Padang. Pengumpulan data dilakukan melalui kuisioner, pengukuran tinggi, dan berat badan anak. Analisa data dilakukan dengan menggunakan uji statistik Chi-Square. Hasil penelitian didapatkan status gizi murid SD di pusat kota dengan tingkat sosial ekonomi baik sebesar $84,2 \%$ status gizi baik dan $6 \%$ status gizi kurang, sedangkan keluarga dengan tingkat sosial ekonomi rendah didapatkan $15,7 \%$ status gizi baik dan $0 \%$ status gizi kurang. Pada daerah pinggiran kota dengan status ekonomi baik didapatkan $15,8 \%$ status gizi baik dan $64,7 \%$ status gizi kurang, sedangkan pada keluarga dengan status ekonomi rendah didapatkan $84,3 \%$ status gizi baik dan $100 \%$ status gizi kurang. Dari uji Chi-Square didapatkan nilai pearson Chi-Square $(x 2)=71.004$ lebih besar dari nilai x2 tabel $=7,815$ dan nilai probabilitas $(p)=0,000$ lebih kecil dari nilai probabilitas yang bermakna yaitu $p<0,05$ berarti terdapat hubungan yang signifikan antara status gizi dengan status sosial ekonomi keluarga murid SD di pusat dan pinggiran kota Padang. Status gizi anak juga berhubungan dengan tingkat ekonomi keluarga, tingkat pendidikan ayah dan ibu serta jumlah anak dalam keluarga.
\end{abstract}

Kata kunci: Status Gizi, Status Sosial Ekonomi, Pusat Kota, Pinggiran Kota

\begin{abstract}
Nutritional status of children is indirectly related to socioeconomic factors. If the low socioeconomic status family meals needs will not fulfilled so that the child will have malnutrition status. The purpose of this study was to determine the relationship of nutritional status and family socioeconomic status elementary students in the center and suburbs of Padang. An analytic study is cross-sectional was conducted on 220 students at SDN 08 Alang Lawas as representatives elementary in the city center of Padang and SDN 36 Koto Panjang as a representative elementary school on the in the suburbs of Padang. Data collection was conducted through questionnaires and measurements of height and weight of children. Data analysis was done using Chi-Square test statistics. The results were obtained nutritional status in the city center with good socioeconomic level of $84.2 \%$ obtained a good nutritional status and $6 \%$ malnutrition, while families with lower socioeconomic levels obtained $15.7 \%$ of good nutritional status and $0 \%$ malnutrition. In the suburban areas with good economic status of $15.8 \%$ obtained a good nutritional status and $64.7 \%$ malnutrition status, while in families with low socioeconomic status obtained $84.3 \%$ a good nutritional status and $100 \%$ malnutrition. Of the Chi-Square test obtained value Pearson Chi-Square $(x 2)=71004$ is greater than the table value $x 2=7.815$ and the probability value $(p)=0.000$ is smaller than the value that is meaningful probability $p<0.05$ means that there is a significant relationship between the nutritional status of the family's socioeconomic status elementary students in the center and suburbs the city of Padang. Nutritional status associated with Economic level of families, father and mother's education level and number of children in families.
\end{abstract}

Keywords:Nutritional Status, Socioeconomic Status, The City Center, Suburbs

Affiliasi penulis : Fakultas Kedokteran Universitas Andalas Korespondensi :Lisbet Rimelfhi Sebataraja, Email: debataraja_lisbet@yahoo.com, Telp: 085274130781

\section{PENDAHULUAN}

Keberhasilan pembangunan suatu bangsa sangat tergantung kepada keberhasilan bangsa itu menyiapkan sumber daya manusia yang berkualitas, sehat, cerdas, dan produktif. ${ }^{1}$ Walaupun sumber alam yang tersedia bagi suatu bangsa berlimpah tanpa adanya sumber daya manusia yang tangguh maka sulit diharapkan untuk berhasil membangun bangsa itu sendiri. Kemiskinan dan kurang gizi masih menjadi masalah bagi bangsa Indonesia yang tidak kunjung berkesudahan. $^{2}$

Kurang gizi pada awal kehidupan karena kurangnya zat gizi yang diterima ibu saat mengandung dapat menyebabkan janin mengalami kurang gizi dan lahir dengan berat badan rendah. Anak yang lahir akan mempunyai konsekuensi kurang menguntungkan dalam kehidupan berikutnya. Sebagai akibat lebih lanjut dari tingginya angka Bayi Berat Lahir Rendah (BBLR) dan kurang gizi pada masa balita dan tidak adanya pencapaian perbaikan pertumbuhan yang 
sempurna pada masa berikutnya, maka tidak heran apabila pada usia sekolah banyak ditemukan anak yang kurang gizi. ${ }^{2}$

Menurut Riset Kesehatan Dasar (Riskesdas) 2010, prevalensi kependekan dan kekurusan tertinggi terjadi pada kelompok anak usia sekolah atau anak umur 6-12 tahun. Lebih dari sepertiga (35,6\%) anak usia sekolah di Indonesia tergolong pendek yang merupakan indikator adanya kurang gizi kronis. Prevalensi anak pendek semakin meningkat dengan bertambahnya umur dan gambaran ini ditemukan baik pada laki-laki maupun perempuan. ${ }^{3}$

Pada masa usia sekolah, anak membutuhkan lebih banyak zat gizi untuk pertumbuhan dan beraktivitas. Hal ini disebabkan karena pada masa ini terjadi pertumbuhan fisik, mental, intelektual, dan sosial secara cepat, sehingga golongan ini perlu mendapat perhatian khusus.Faktor kecukupan gizi ditentukan oleh kecukupan konsumsi pangan dan kondisi keluarga. Unicef dan Johnson (1992) membuat model interelasi tumbuh kembang anak dengan melihat penyebab langsung, sebab tidak langsung dan penyebab dasar. Sebab langsung adalah kecukupan makanan dan keadaan kesehatan.Penyebab tidak langsung meliputi ketahanan makanan keluarga, asuhan bagi ibu dan anak, sanitasi lingkungan dan pemanfaatan pelayanan kesehatan. Penyebab yang paling mendasar dari tumbuh kembang anak adalah masalah struktur politik dan ideologi serta struktur ekonomi yang dilandasi oleh potensi sumber daya.Disamping itu, berbagai faktor sosial ekonomi ikut mempengaruhi pertumbuhan anak. Faktor sosial ekonomi tersebut antara lain: pendidikan, pekerjaan, pendapatan keluarga, budaya, dan teknologi. Fakorfaktor tersebut berinteraksi satu dengan yang lainnya sehingga dapat mempengaruhi masukan zat gizi dan infeksi pada anak. Pada akhirnya ketersediaan zat gizi pada tingkat seluler rendah dan mengakibatkan pertumbuhan terganggu. ${ }^{4}$

Jumlah dan kualitas makanan keluarga ditentukan oleh tingkat pendapatan keluarga.Pada umumnya kemiskinan menduduki posisi pertama sebagai penyebab gizi kurang, sehingga perlu mendapat perhatian yang serius karena kemiskinan berpengaruh besar terhadap konsumsi makanan. ${ }^{5} \mathrm{Di}$ provinsi Sumatra Barat jumlah penduduk miskin pada bulan September 2011 adalah 441.799 jiwa. Lebih dari dua pertiga $(67,18 \%)$ penduduk miskin tinggal di daerah pedesaan dan $32 \%$ penduduk tinggal di perkotaan. $^{6} \mathrm{Hal}$ ini pun berhubungan dengan prevalensi kurang gizi yang lebih tinggi di pedesaan dibandingkan di perkotaan. Kemenkes RI mencatat anak yang pendek diperkotaan sebesar 29,3\% dan $41,5 \%$ anak di perdesaan. Anak yang kurus di perkotaan sebesar $11,9 \%$ dan di perdesaan sebesar $12,5 \%{ }^{3}$

Kemiskinan atau pendapatan keluarga yang rendah sangat berpengaruh kepada kecukupan gizi keluarga.Kekurangan gizi berhubungan dengan sindroma kemiskinan. Tanda-tanda sindroma kemiskinan antara lain berupa: penghasilan yang sangat rendah sehingga tidak dapat mencukupi kebutuhan, sandang, pangan, dan perumahan; kuantitas dan kualitas gizi makanan yang rendah; sanitasi lingkungan yang jelek dan sumber air bersih yang kurang, akses terhadap pelayanan yang sangat terbatas; jumlah anggota keluarga yang banyak, dan tingkat pendidikan yang rendah.
Masyarakat yang tergolong miskin dan berpendidikan rendah merupakan kelompok yang paling rawan gizi. Hal ini disebabkan oleh rendahnya kemampuan untuk menjangkau pangan yang baik secara fisik dan ekonomis.

Kelompok anak usia sekolah merupakan salah satu kelompok rentan gizi. Meskipun kelompok umur ini mempunyai kesehatan yang lebih baik dibandingkan kesehatan anak balita, tetapi kelompok ini dapat timbul masalah-masalah kesehatan, seperti: berat badan rendah, defisiensi zat besi, dan defisiensi vitamin $\mathrm{E}^{8}$

Anak usia sekolah dengan kondisi ekonomi keluarga baik yang bersekolah di pusat kota memungkinkan anak memiliki status kesehatan yang lebih baik dibandingkan dengan anak yang bersekolah dan tinggal di pinggiran kota. Pusat kota merupakan tempat yang memiliki pusat pelayanan yang tinggi untuk memenuhi kebutuhan, seperti: fasilitas pertokoan, perbelanjaan, fasilitas untuk mengakses informasi dan kesehatan. Sedangkan, anak yang bersekolah dan tinggal di daerah pinggiran kota dengan segala fasilitas yang tersedia dan kondisi sosial ekonomi keluarga yang terbatas memungkinkan anak mempunyai status kesehatan dan gizi yang buruk dibandingkan dengan anak yang tinggal di pusat kota.

Dari hasil observasi ditentukan SDN 08 Alang Lawas Kecamatan Padang Selatan merupakan SD yang berada di Pusat Kota Padang dan SDN 36 Koto Panjang Kecamatan Koto Tangah merupakan SD yang berada di pinggiran kota Padang. Berdasarkan hasil observasi, penulis tertarik untuk mengetahui apakah terdapat pengaruh sosial ekonomi keluarga murid sekolah dasar yang berada di daerah pusat kota dan pinggiran kota dengan status gizi anak.

\section{METODE}

Penelitian ini mengunakan metode analitik dengan pendekatan cross sectional. Waktu penelitian dilaksanakan pada bulan Juli 2012 - September 2013. Penelitian dilakukan di SDN yang berada di Pusat Kota Padang yaitu SDN 08 Alang Lawas di Kecamatan Padang Selatan dan SDN 36 Koto Panjang di Kecamatan Koto Tangah sebagai perwakilan sekolah di pinggiran Kota Padang. Populasi adalah murid yang bersekolah di SDN 08 Alang Lawas dan SDN 36 Koto Panjang. Sampel diambil dari populasi dengan rumus diatas karena jumlah populasi kurang dari 10.000 , dimana $d=0,05$ sehingga didapatkan jumlah sampel 220 orang. Sampel dari setiap sekolah yang diambil adalah 110 orang.

Variabel dependen penelitian adalah status gizi yang dinyatakan berdasarkan klasifikasi menurut Waterlow yang menggunakan indeks $\mathrm{BB} / \mathrm{TB}$ dan $\mathrm{TB} / \mathrm{U}$. Alat yang digunakan untuk menimbang berat badan anak yaitu timbangan injak digital dengan kapasitas $150 \mathrm{~kg}$ dan ketelitian 0,1 gr dan hasilnya dikonversikan ke dalam bentuk nilai terstandar ( $Z$ score) dengan menggunakan baku antropometri balita WHO-NCHS. Hasil ukurnya yaitu gizi baik (normalnormal) dan gizi kurang (normal-rendah, rendahnormal, dan rendah-rendah).

Variabel independen adalah umur, status sosial ekonomi keluarga yaitu keluarga, jumlah anak dalam keluarga, tingkat pendidikan orang tua, tempat tinggal (pusat kota dan pinggiran kota). 
Data didapatkan dari pengisian kuisioner, pengukuran tinggi badan dan berat badan anak. Langkah-langkah pengolahan data yang dilakukan yaitu memeriksa kelengkapan data dari kuesioner, memberikan kode pada setiap data variabel yang telah terkumpul, memasukkan data ke dalam komputer dengan program Microsoft Excell dan Statistical Program for Social Science (SPSS) 17.0, dan memeriksa kembali data yang telah dimasukkan untuk memastikan bahwa data tersebut telah bersih dari kesalahan. Analisis data terdiri dari analisis univariat dan bivariat. Analisis bivariat digunakan untuk mengetahui hubungan antara dua variabel yaitu diare dengan status gizi menggunakan uji Chi-square dengan derajat kemaknaan $\mathrm{p}<0,05$.

\section{HASIL}

\section{Karakteran Sampel}

-Tingkat Pendidikan Orang Tua:

Tingkat pendidikan orang tua murid SD di Pusat Kota Padang yang terbanyak adalah tingkat pendidikan tinggi yaitu $92,7 \%$ pada ayah dan $96,4 \%$ pada ibu. Sedangkan di Pinggiran Kota Padang terbanyak adalah tingkat pendidikan rendah yaitu $74.5 \%$ pada ayah dan $65.5 \%$ pada ibu.

Tabel 1. Distribusi Frekuensi Tingkat Pendidikan Ayah dan Ibu Murid SDN 08 Alang Lawas dan SDN 36 Koto Panjang.

\begin{tabular}{ccccccccccc}
\hline \multirow{2}{*}{$\begin{array}{c}\text { Tingkat } \\
\text { Pendidik } \\
\text { an }\end{array}$} & \multicolumn{2}{c}{ SDN 08 Alang Lawas } & \multicolumn{2}{c}{ SDN 36 Koto Panjang } \\
\cline { 2 - 11 } & Fyah & \multicolumn{2}{c}{ lbu } & \multicolumn{2}{c}{ Ayah } & \multicolumn{2}{c}{ Ibu } \\
\cline { 2 - 11 } & $\%$ & F & $\%$ & F & $\%$ & F & $\%$ \\
\hline Tinggi & 102 & 92.7 & 106 & 96.4 & 28 & 25.5 & 38 & 34.5 \\
Rendah & 8 & 7.3 & 4 & 3.6 & 82 & 74.5 & 72 & 65.5 \\
\hline Jumlah & 110 & 100 & 110 & 100 & 110 & 100 & 110 & 100 \\
\hline
\end{tabular}

-Status Ekonomi Keluarga:

Tabel 2. Distribusi Frekuensi Tingkat Ekonomi Keluarga Murid SDN 08 Alang Lawas dan SDN 36 Koto Panjang

\begin{tabular}{ccccc}
\hline \multirow{2}{*}{$\begin{array}{c}\text { Tingkat } \\
\text { Ekonomi }\end{array}$} & \multicolumn{2}{c}{$\begin{array}{c}\text { SDN 08 Alang } \\
\text { Lawas }\end{array}$} & \multicolumn{2}{c}{$\begin{array}{c}\text { SDN 36 Koto } \\
\text { Panjang }\end{array}$} \\
\cline { 2 - 5 } & $\mathbf{F}$ & $\%$ & $\mathbf{F}$ & $\%$ \\
\hline Miskin & 7 & 6.36 & 81 & 73.64 \\
Tidak Miskin & 103 & 93.64 & 29 & 26.36 \\
\hline Jumlah & 110 & 100 & 110 & 100 \\
\hline
\end{tabular}

Tingkat ekonomi keluarga murid SD di pusat kota Padang yaitu $93,64 \%$ golongan keluarga tidak miskin dan 6,36\% keluarga yang miskin. Di pinggiran kota Padang yaitu $26,36 \%$ keluarga tidak miskin dan $73,64 \%$ keluarga miskin.

-Jumlah Anak dalam Keluarga:

Tabel 3. Distribusi frekuensi jumlah anak dalam keluarga pada murid SDN 08 Alang lawas dan SDN 36 Koto Panjang.

\begin{tabular}{ccccc}
\hline \multirow{2}{*}{ Jumlah Anak } & \multicolumn{2}{c}{$\begin{array}{c}\text { SDN 08 Alang } \\
\text { Lawas }\end{array}$} & \multicolumn{2}{c}{$\begin{array}{c}\text { SDN 36 Koto } \\
\text { Panjang }\end{array}$} \\
\cline { 2 - 5 } & $\mathbf{F}$ & $\%$ & F & $\%$ \\
\hline 2 orang & 44 & 40 & 18 & 16.36 \\
$>2$ orang & 66 & 60 & 92 & 83.64 \\
\hline Jumlah & 110 & 100 & 110 & 100.00 \\
\hline
\end{tabular}

Jumlah anak dalam keluarga murid SD di pusat kota adalah $60 \%$ keluarga yang memiliki anak lebih dari 2 orang dan $40 \%$ keluarga dengan anak kecil sama dengan 2 orang. Di pinggiran kota Padang $16,36 \%$ keluarga memiliki anak kecil sama dengan 2 orang dan $83,64 \%$ keluarga dengan jumlah anak lebih dari 2 orang.

\section{-Tinggi dan Berat Badan:}

Rata-rata tinggi dan berat badan keseluruhan murid SDN 08 Alang lawas adalah 130,46 cm dan $29,54 \mathrm{~kg}$. Rata-rata tinggi dan berat badan keseluruhan murid SDN 36 Koto Panjang adalah $125,21 \mathrm{~cm}$ dan 23,86. Perbedaan rata-rata tinggi dan berat badan di kedua sekolah ini sebesar $5,25 \mathrm{~cm}$ dan $5,68 \mathrm{~kg}$.

Tabel 4. Tinggi dan Berat Badan Rata-rata Murid SDN 08 Alang Lawas dan SDN 36 Koto Panjang berdasarkan umur anak

\begin{tabular}{ccccc}
\hline \multirow{2}{*}{ Umur } & \multicolumn{2}{c}{ SDN 08 Alang Lawas } & \multicolumn{2}{c}{$\begin{array}{c}\text { SDN 36 Koto } \\
\text { Panjang }\end{array}$} \\
\cline { 2 - 5 } & $\begin{array}{c}\text { Rata-rata } \\
\text { TB (cm) }\end{array}$ & $\begin{array}{c}\text { Rata-rata } \\
\text { BB (kg) }\end{array}$ & $\begin{array}{c}\text { Rata- } \\
\text { rata TB } \\
\text { (cm) }\end{array}$ & $\begin{array}{c}\text { Rata-rata } \\
\text { BB (kg) }\end{array}$ \\
\hline 6 & 116.07 & 23.64 & 114.3 & 18.36 \\
7 & 121.87 & 24.29 & 113.58 & 18.35 \\
8 & 125,50 & 24.03 & 120.87 & 20.94 \\
9 & 131.26 & 30.72 & 125.95 & 23.96 \\
10 & 138.04 & 34.25 & 131.03 & 27.96 \\
11 & 142.31 & 38.39 & 133.42 & 28.15 \\
12 & 138.20 & 31.45 & 137.32 & 29.34 \\
\hline $\begin{array}{c}\text { Rata- } \\
\text { rata }\end{array}$ & 130.46 & 29.54 & 125.21 & 23.86 \\
\hline
\end{tabular}


-Status Gizi Menurut Klasifikasi Waterlow:

Tabel 5. Status Gizi Menurut Klasifikasi Waterlow pada Murid SDN 08 Alang Lawas dan SDN 36 Koto Panjang

\begin{tabular}{lcccc}
\hline $\begin{array}{c}\text { Status Gizi Klasifikasi } \\
\text { Waterlow }\end{array}$ & \multicolumn{2}{c}{$\begin{array}{c}\text { SDN 08 Alang } \\
\text { Lawas }\end{array}$} & \multicolumn{2}{c}{$\begin{array}{c}\text { SDN 36 Koto } \\
\text { Panjang }\end{array}$} \\
\cline { 2 - 5 } & F & $\%$ & F & $\%$ \\
\hline Gizi Baik & 104 & 94.6 & 61 & 55.5 \\
$\begin{array}{l}\text { Gizi Kurang } \\
\text { Acute Malnutrition }\end{array}$ & 1 & 0.9 & 5 & 4.5 \\
$\begin{array}{l}\text { Post Malnutrition } \\
\text { Cronic Prolonged } \\
\text { Malnutrition }\end{array}$ & 5 & 4.5 & 40 & 36.4 \\
\hline \multicolumn{1}{c}{ Jumlah } & 0 & 0 & 4 & 3.6 \\
\hline
\end{tabular}

Status gizi menurut klasifikasi Waterlow dengan status gizi baik lebih banyak pada murid SD yang bersekolah di pusat kota Padang (94,6\%) dibandingkan pada murid SD di pinggiran kota Padang (55,5\%). Sedangkan, status gizi kurang lebih banyak pada murid SD di pinggiran kota Padang (44,5\%) dibandingkan pada murid SD yang bersekolah di pusat kota Padang $(5,4 \%)$.

Hubungan Status Gizi Anak dengan Tingkat Pendidikan Orang Tua

-Hubungan Status Gizi dengan Pendidikan Ayah:

Tabel 6. Hubungan Status Gizi dengan Pendidikan Ayah

\begin{tabular}{|c|c|c|c|c|c|c|}
\hline \multirow{3}{*}{ Status Gizi } & \multicolumn{4}{|c|}{ Pendidikan ayah } & \multirow{3}{*}{ Jumlah } & \multirow{3}{*}{$\begin{array}{c}\mathbf{p} \\
\text { value }\end{array}$} \\
\hline & \multicolumn{2}{|c|}{ Tinggi } & \multicolumn{2}{|c|}{ Rendah } & & \\
\hline & $\mathbf{F}$ & $\%$ & $F$ & $\%$ & & \\
\hline Gizi Baik & 111 & 67.3 & 54 & 32.7 & 155 & \\
\hline Gizi Kurang & 19 & 34.5 & 36 & 65.5 & 55 & 0.000 \\
\hline Jumlah & 130 & 59.1 & 90 & 40.9 & 220 & \\
\hline
\end{tabular}

-Hubungan Status Gizi dengan Pendidikan Ibu:

Tabel 7. Hubungan Status Gizi dengan Pendidikan lbu

\begin{tabular}{|c|c|c|c|c|c|c|}
\hline \multirow{3}{*}{$\begin{array}{c}\text { Status } \\
\text { Gizi }\end{array}$} & \multicolumn{4}{|c|}{ Pendidikan Ibu } & \multirow{3}{*}{ Jumlah } & \multirow{3}{*}{$\begin{array}{c}p \\
\text { value }\end{array}$} \\
\hline & \multicolumn{2}{|c|}{ Tinggi } & \multicolumn{2}{|c|}{ Rendah } & & \\
\hline & $\mathbf{F}$ & $\%$ & $\mathbf{F}$ & $\%$ & & \\
\hline Gizi Baik & 117 & 70.9 & 48 & 29.1 & 165 & \\
\hline $\begin{array}{c}\text { Gizi } \\
\text { Kurang } \\
\end{array}$ & 27 & 49.1 & 28 & 50.9 & 55 & 0.003 \\
\hline Jumlah & 144 & 65.5 & 76 & 34.5 & 220 & \\
\hline
\end{tabular}

Hubungan Status Gizi dengan Tingkat Ekonomi Keluarga

Tabel 8. Hubungan Status Gizi dengan Status Ekonomi

\begin{tabular}{|c|c|c|c|c|c|c|}
\hline \multirow{3}{*}{ Status Gizi } & \multicolumn{4}{|c|}{ Status Ekonomi } & \multirow{3}{*}{ Jumlah } & \multirow{3}{*}{$\begin{array}{c}p \\
\text { value }\end{array}$} \\
\hline & \multicolumn{2}{|c|}{ Tidak Miskin } & \multicolumn{2}{|c|}{ Miskin } & & \\
\hline & $\mathbf{F}$ & $\%$ & $F$ & $\%$ & & \\
\hline Gizi Baik & 114 & 69.1 & 51 & 30.9 & 165 & \\
\hline Gizi Kurang & 17 & 30.9 & 38 & 69.1 & 55 & 0.000 \\
\hline Jumlah & 131 & 59.5 & 89 & 40.5 & 220 & \\
\hline
\end{tabular}

Hubungan Status Gizi dengan Jumlah Anak dalam Keluarga

Tabel 9. Hubungan Status Gizi dengan Jumlah Anak dalam Keluarga

\section{Distribusi Jumlah Anak}

Status Gizi kecil sama 2 besar dari 2 Jumlah $\begin{gathered}p \\ \text { value }\end{gathered}$

\begin{tabular}{ccccccc}
\cline { 2 - 5 } & $\mathbf{F}$ & $\%$ & $\mathbf{F}$ & $\%$ & & \\
\hline Gizi Baik & 54 & 32.7 & 111 & 67.3 & 165 & \\
Gizi Kurang & 8 & 14.5 & 47 & 85.5 & 55 & 0.009 \\
\cline { 1 - 5 } Jumlah & 62 & 28.2 & 158 & 71.8 & 220 & \\
\cline { 1 - 3 }$x^{2}=6.737 ; p=0.009(p>0.05)$ & & &
\end{tabular}

Hubungan Tempat Tinggal terhadap Status gizi Tabel 10. Hubungan tempat tinggal terhadap Status gizi

\begin{tabular}{ccccccc}
\hline & \multicolumn{4}{c}{ Daerah Sekolah } & & \\
\cline { 2 - 5 } Status Gizi & \multicolumn{2}{c}{ Pinggiran Kota } & $\begin{array}{c}\text { Pusat } \\
\text { Kota }\end{array}$ & Jumlah & $\begin{array}{c}\mathbf{p} \\
\text { value }\end{array}$ \\
\cline { 2 - 5 } & $\mathbf{F}$ & $\%$ & $\mathbf{F}$ & $\%$ & & \\
\hline Gizi Baik & 61 & 37 & 104 & 63 & 165 & \\
Gizi Kurang & 49 & 89.1 & 6 & 10.9 & 55 & 0.000 \\
\hline Jumlah & 110 & 50 & 110 & 50 & 220 & \\
\hline$X^{2}=44.824 ;$ & $p=0.000(p<0.05)$ & & &
\end{tabular}

PEMBAHASAN

Hubungan Status Gizi Anak dengan Tingkat Pendidikan Orang Tua

Tingkat pendidikan orang tua murid sekolah dasar di pusat kota lebih tinggi dari pada di pinggiran kota. Dari uji statistik didapatkan hubungan yang signifikan tingkat pendidikan orang tua terhadap status gizi pada murid Sekolah Dasar di pusat dan pinggiran kota. Tingkat pendidikan orang tua turut menentukan 
status gizi anak karena pendidikan sangat mempengaruhi seseorang untuk memahami dan menerima informasi tentang gizi. Masyarakat dengan pendidikan yang rendah akan lebih mempertahankan tradisi-tradisi yang berhubungan dengan makanan sehingga sulit menerima pengetahuan baru mengenai gizi. ${ }^{5,10,22}$

Menurut Yudesti (2012) dan Ernawati (2006) semakin tinggi tingkat pendidikan orang tua semakin baik pertumbuhan anaknya. Schultz, (1984) menjelaskan setidaknya ada lima upaya yang merupakan imbas dari pendidikan ibu dan ayah yang dapat mempengaruhi pertumbuhan dan perkembangan anak. Pertama, pendidikan akan meningkatkan sumberdaya keluarga. Kedua, pendidikan akan meningkatkan pendapatan keluarga. Ketiga, pendidikan akan meningkatkan alokasi waktu untuk pemeliharaan kesehatan anak. Keempat, pendidikan akan meningkatkan produktivitas dan efektifitas pemeliharaan kesehatan. Kelima, pendidikan akan meningkatkan referensi kehidupan keluarga. ${ }^{11,12}$

\section{Hubungan Status Gizi dengan Tingkat Ekonomi Keluarga}

Faktor ekonomi merupakan suatu penentu status gizi yang dapat mempengaruhi status gizi anak. Status ekonomi yang rendah atau kemiskinan menduduki posisi pertama pada masyarakat yang menyebabkan gizi kurang. ${ }^{5}$ Status gizi baik pada murid dengan tingkat ekonomi keluarga tidak miskin 69,1\% dan $30,9 \%$ pada keluarga miskin sedangkan status gizi kurang pada murid sekolah dasar dengan tingkat keluarga tidak miskin $30,9 \%$ dan $69,1 \%$ pada keluarga miskin. Dari uji statistik didapatkan hubungan yang nyata antara status ekonomi kelurga terhadap status gizi anak. Gusman (2002) dan Khair (2007) pernah melakukan penelitian yang sama dan didapatkan hubungan yang nyata antara status ekonomi dan status gizi. ${ }^{13,14}$ Faktor sosial ekonomi meliputi pendidikan, pekerjaan, teknologi, budaya, dan pendapatan keluarga ikut mempengaruhi pertumbuhan anak. Faktor ini akan berinteraksi satu dengan yang lain sehingga mempengaruhi masukan zat gizi. ${ }^{4}$ Keadaan ekonomi keluarga yang baik dapat menjamin terpenuhinya kebutuhan pokok setiap anggota keluarga. ${ }^{15}$ Kekurangan gizi pada anak-anak merupakan masalah kesehatan masyarakat karena sumber dayanegara yang miskin.Sebuah studi multinegara mengenai status antropometri anak sekolah pedesaan diGhana, Tanzania,Indonesia, Vietnam, dan India ditemukanprevalensi pendek dan kurus, mulaidari $48 \%$ menjadi $56 \%$ untuk pendek dan dari $34 \%$ menjadi $62 \%$ untuk kurus. $^{16}$

\section{Hubungan Status Gizi dengan Jumlah Anak dalam Keluarga}

Jumlah anggota keluarga berperan dalam pertumbuhan, yaitu pada keluarga kecil pertumbuhan anak lebih baik dibandingkan pada keluarga besar. ${ }^{17,18}$ Pada penelitian ini didapatkan hubungan yang signifikan antara jumlah anak dalam keluarga dan status gizi. Walaupun pada kedua daerah memiliki jumlah anak terbanyak adalah anak lebih dari 2 orang $60 \%$ di pusat kota Padang dan 83, 64 di pinggiran kota padang. Gizi kurang sebesar $85,5 \%$ diderita oleh keluarga dengan jumlah anak lebih dari 2 orang. Keluarga akan lebih mudah memenuhi kebutuhan makanan jika jumlah anggota keluarga sedikit. ${ }^{5}$ Penilaian status gizi dapat memberikan informasi tentang keadaan gizi suatu masyarakat pada saat sekarang dan masa lampau. Gizi kurang pada anak dapat menyebabkan anak menjadi kurus dan pertumbuhan terhambat. ${ }^{8}$ Arlim (2002) menyatakan terdapat pengaruh tingkat sosial ekonomi terhadap status gizi anak pada anak jumlah anak dalam keluarga kurang dari 4 orang pada beberapa Sekolah Dasar di Kota Padang. ${ }^{7}$ Khair (2007) juga menyatakan terdapat hubungan yang bermakna antara status gizi dengan jumlah anak dalam keluarga. ${ }^{14}$ Sedangkan, penelitian Astuti FD (2012) di Kecamatan Godean Yogyakarta didapatkan tidak ada hubungan tingkat pendapatan dengan status gizi pada anak. Penelitian ini tidak menunjukan adanya hubungan antara pendapatan dengan status gizi pada anak dapat di karenakan pendapatan keluarga yang kurang dari UMR masih dapat mencukupi kebutuhan makanan keluarga sehingga status gizinya normal. Konsumsi barang di tingkat keluarga lebih banyak dipengaruhi oleh tingkat pendapatan keluarga dibandingkan oleh faktor bentuk keluarga. ${ }^{19}$

\section{Hubungan Tempat Tinggal terhadap Status gizi}

Secara statistik terdapat hubungan status gizi dengan daerah tempat sekolah anak. Murid Sekolah Dasar di pusat kota sebagian besar $(63 \%)$ memiliki status gizi baik dan $10,9 \%$ status gizi kurang, sedangkan pada murid Sekolah Dasar di pinggiran kota hanya terdapat $37 \%$ anak dengan status gizi baik dan $89,1 \%$ anak dengan status gizi kurang. Hal ini dipengaruhi oleh fasilitas yang tersedia di daerah masing-masing serta tingkat pengetahuan orang tua. Pusat kota merupakan pusat pelayanan paling tinggi untuk memenuhi kebutuhan, pada daerah ini banyak tersedia fasilitas yang menunjang pengetahuan mengenai gizi, tempattempat perbelanjaan yang mempermudah penduduk mendapatkan variasi jenis makanan, dan akses kesehatan yang lengkap. Sedangkan, anak yang bersekolah dan berdomisili di pinggiran kota hanya memiliki fasilitas yang terbatas. ${ }^{21}$

Terdapat hubungan yang nyata antara status gizi dengan status ekonomi keluarga murid sekolah dasar di pusat dan pinggiran kota. Di Negara-negara yang berpenghasilan rendah, terutama diperkotaan, dua pertiga bagian dari jumlah pengeluaran digunakan untuk konsumsi makanan.Masalah ekonomi, sosial dan politik dapat mengakibatkan meningkatnya inflasi (harga makanan naik). Inflasi harga pangan dapat mengakibatkan kegagalan dalam segi distribusi bahan makanan dan daya beli masyarakat menjadi rendah. ${ }^{5}$ Status ekonomi yang rendah atau kemiskinan selalu berkaitan dengan kekurangan makanan, kesehatan lingkungan yang jelek, dan ketidaktahuan akan berakibat terhambatnya pertumbuhan anak. ${ }^{1}$

Dekker 2010 melakukan peneltian di Colombia menyatakan dalam beberapa studi yang dilakukan pada anak usia sekolah dari negara berkembang, status sosial ekonomi rendah adalahfaktor risiko penting terjadinyakekurusan pada anak. Misalnya, di Brasilprevalensi kurus jauh lebih rendah di antara anak-anak dari sekolah swasta yang kaya (2,3\%) dibandingkan anak sekolah dari masyarakat miskin $(6,2 \%$ menjadi $15,2 \%)$. Di Chile, kekerdilan anak usia sekolah dikaitkan dengan kurangnyaasuransi kesehatan, kondisi perumahan tidak higienis, dan riwayat gizi buruk. Di Colombia, kurus dikaitkan dengan pendidikan ibu rendah. Hubungan ini bisa dipengaruhi oleh minimnya pengetahuan kesehatan yang memadai dan perilaku gizi atau terbatasan akses dan penggunaan pelayanan kesehatan. ${ }^{20}$ 
Berdasarkan penelitian ini dapat disimpulkan bahwa terdapat hubungan antara status gizi dengan daerah tempat tinggal anak, terhadap tingkat pendidikan orang tua, terhadap jumlah anak dalam keluarga, dan terhadap status ekonomi keluarga murid sekolah dasar di pusat dan pinggiran kota Padang.

\section{DAFTAR PUSTAKA}

1. Tanuwijaya S. Kebutuhan dasar tumbuh kembang anak. Dalam: (Ikatan Dokter Anak Indonesia) Tumbuh Kembang Anak dan Remaja. Edisi ke-1. Jakarta: Sagung Seto; 2002. hlm.13.

2. Hadi $H$. Beban ganda masalah gizi dan implikasinya terhadap kebijakan pembangunan kesehatan nasional. Yogyakarta: Universitas Gadjah Mada Press; 2005. hlm.3-6.

3. Kemenkes RI. Riset kesehatan indonesia (RISKESDAS) 2010. Jakarta: Badan Penelitian dan Pengembangan Kesehatan Kementerian Kesehatan RI; 2010.hlm.38-48 (diunduh 16 April 2012). Tersedia dari: URL: HYPERLINK http://www.riskesdas.litbang.depkes.go.id

4. Supariasa IDN, Bakri B, Fajar I. Penilaian status gizi. Jakarta: EGC; 2001. hlm.17-85.

5. Suhardjo. Perencanaan pangan dan gizi. Edisi ke-1. Jakarta: Bumi Aksara; 2005. hlm.5-10.

6. BPS. Berita resmi statistik: Profil kemiskinan Provinsi Sumatera Barat September 2011. Katalog no.05/01/13/Th.XV/2 Januari 2012.

7. Arlim SM. Pengaruh perbandingan tingkat sosial ekonomi keluarga terhadap status gizi murid kelas 1 pada beberapa SD di kota Padang (skripsi). Padang: Fakultas Kedokteran Universitas Andalas; 2002.

8. Roedjito D. Kajian penelitian gizi. Edisi ke-1. Jakarta: Mediyatama Sarana Perkasa; 1989. hlm. 1-43.

9. Notoatmodjo S. IImu kesehatan masyarakat, prinsip-prinsip dasar. Jakarta: Rineka Cipta; 1997.

10. Kurniawati E. Hubungan tingkat pengetahuan ibu tentang gizi dengan status gizi balita di kelurahan Baledono, kecamatan Purworejo, kabupaten Purworejo. Gizi Indonesia. 2001;34(1):22-31.

11. Yudesti I, Prayitno N. Perbedaan status gizi anak SD kelas IV dan V Di SD Unggulan (06 Pagi Makasar) dan SD Non Unggulan (09 Pagi Pinang Ranti) Kecamatan Makasar Jakarta Timur Tahun 2012. Jurnal IImiah Kesehatan. 2012;5(1):1-5.
12. Ernawati A. Hubungan faktor sosial ekonomi, higiene sanitasi lingkungan, tingkat konsumsi, dan infeksi dengan status gizi anak usia 2-5 tahun di Kabupaten Semarang tahun 2003 (tesis). Semarang: Program Pasca Sarjana Magister Gizi Masyarakat Universitas Diponegoro; 2006.

13. Gusman Y. Perbandingan tinggi serta berat badan murid SD pada beberapa sekolah dasar di kecamatan Lubuk Kilangan kodya Padang (skripsi). Padang: Universitas Andalas.

14. Khair NE. Status gizi murid kelas 1 sekolah dasar di kelurahan Pasir Nan Tigo Kecamatan Kota Tangah (skripsi). Padang: Universitas Andalas; 2007.

15. Suryanah. Keperawatan anak untuk siswa SPK, Jakarta: EGC; 1996

16. Osei A, Houser R, Bulusu S, Joshi T, Hamer D. Nutritional status of primary school children in Garhwali Himalayan villages of India. Food and Nutrition Bulletin. 2010;31(2): 221-33.

17. Suyitno $H$, Narendra MB. Pertumbuhan fisik anak. Dalam: (Ikatan Dokter Anak Indonesia) Tumbuh Kembang Anak dan Remaja. Edisi ke-1. Jakarta: Sagung Seto; 2002. hlm. 55.

18. Puspitasari D, Sudargo T, Gamayanti IL. Hubungan antara status gizi dan faktor sosiodemografi dengan kemampuan kognitif anak sekolah dasar di daerah endemis GAKI. Gizi Indonesia. 2011;34(1):52-60.

19. Astuti FD, Sulistyowati TF. Pendapatan Keluarga dengan Status Gizi Anak Prasekolah dan Sekolah Dasar Di Kecamatan Godean. ISSN: 1978-0575. 2012; 7(1): 15-20.

20. Dekker LH, Mora-Plazas M, Marin C, Baylin A, Villamor E. Stunting associated with poor socioeconomic and maternal nutrition status and respiratory morbidity in Colombian schoolchildren. Food and Nutrition Bulletin. 2010; (31): 242-50.

21. Insaf $M$. Fenomena urbanisasi kawasan pinggiran Kota Jakarta (tesis). Semarang: Program Pasca Sarjana Magister Teknik Pembangunan Kota Universitas Diponegoro; 2004. hlm.40-8.

22. Kamiya Y. Socioeconomic determinants of nutritional status of children in Lao PDR: effects of household and community factors. $J$ Health Popul Nutrition 2011;(4): 339-48. 